duced by B cells from two patients with $\mathrm{CVH}$ and one patients with IgM-deficiency that could produce no IgM upon coculturing with normal $\mathrm{T}$ cells and PWM (Fig 2). However, there was no restoration to produce $\operatorname{Ig} G$ or $\operatorname{IgA}$ in these patients. In addition, B cells from 2 patients with IgA-D produced not only $\operatorname{IgG}$ and $\operatorname{Ig} M$, but also IgA almost normally at 4 days after in vitro stimulation with $\mathrm{EBV}^{3)}$.

\section{REFERENCES}

1) Mitsuya $\mathrm{H}$, et al: Evidence for the failure of IgA specific $\mathrm{T}$ helper activity in a patient with immunodeficiency with hyper-IgM. J Clin. Lab. Immunol. 2: 337, 1979.

2) Mitsuya $\mathrm{H}$ et al: T-cell suppression of immunoglobulin synthesis in ataxia telagiectasia: restriction of suppressor activity to $\mathrm{B}$ cells from unrelated donors. Clin Immunol Immunopathol 19: 383, 1981.

3) Mitsuya $\mathrm{H}$, et al: Pathophysiological analysis of peripheral blood lymphocytes from patients with primary immunodeficiency: I. Ig synthesis by peripheral blood lymphocytes stimulated with either PWM or EBV in vitro. J Immunol $127: 311,1981$.

\title{
(5) Idiotype in Patients with Monoclonal Gammopathy
}

\author{
Susumu SugaI, MD \\ The Division of Hematology and Immunology, Department of \\ Internal Medicine, Kanazawa Medical University, \\ Uchinada-machi, Kahoku-gun, Ishikawa Pref.
}

One of the mechanisms capable of regulating the immune response involves the reaction of idiotype (Id) with anti-Id ${ }^{1)}$. In mice, Id-bearing regulatory $\mathrm{T}$ cells and anti-Id immunity have been demonstrated ${ }^{2}$.

We report the $M$ protein Id in 33 patients with monoclonal gammopathy (MG); of these, 9 had multiple myeloma (MM), 7 Waldenström's macroglobulinemia (WM), 3 benign monoclonal gammopathy (BMG), 5 lymphosarcoma (LS), 2 chronic lymphocytic leukemia (GLL), 5 Sjögren's syndrome (SS), 1 common variable immunodeficiency (GVID), and 1 drug allergy.

A. Id in serum and cytoplasmic M proteins

(1) Precipitin reaction between M proteins and anti-Id: The double diffusion method demonstrated Id determinants in 18 of $35 \mathrm{M}$ proteins (Fig 1).

(2) Intracytoplasmic Id : Intracytoplasmic Id was demonstrated in bone marrow cells of various MG patients, in lymph node cells of WM patients, and in cells infiltrating the salivary glands of SS patients.
(3) Antigen-binding capacity and Id of antigen-binding $\mathrm{M}$ proteins (rheumatoid factors): The antigen-binding capacity of 3 momoclonal rheumatoid factors (2 $\operatorname{IgA} \lambda$, $1 \mathrm{IgMK}$ ) was directly related to the Id determinants. Id cross-specificity of one monoclonal rheumatoid factor $(\operatorname{Ig} A \lambda)$ was detected in 4 of 60 sera with rheumatoid factors of other diseases ${ }^{3)}$.

B. T, B cell surface Id

(1) Id determinants were expressed on the cell surface of peripheral blood lymphocytes in 12 patients ${ }^{4}$. In 3 , these lymphocytes were confirmed to be Id-bearing $\mathrm{B}$ cells, indicating that in MG patients, monoclonal change occurs in B cells.

(2) In 7 of 9 patients, the mixed rosette technique demonstrated Id-bearing $\mathrm{T}(\mathrm{T} \gamma$ and $\mathrm{T} \mu$ ) cells in the peripheral blood (Fig $2)^{5}$.

C. In vitro induction of $\mathrm{M}$ protein synthesis by $\mathrm{T}$ and $\mathrm{B}$ cells in the presence of pokeweed mitogen (PWM): Culture of cells from a WM patient and a BMG patient who manifested cytoplasmic Id-containing 
cells less than $0.3 \%$ of PBL demonstrated a small number of cytoplasmic Idcontaining cells.

D. Anti-Id immunity

(1) Id-reactive $\mathrm{T}(\mathrm{T} \gamma$ and $\mathrm{T} \mu)$ cells in human MG: The mixed rosette technique demonstrated $\mathrm{T}(\mathrm{T} \gamma$ and $\mathrm{T} \mu)$ cells reacting

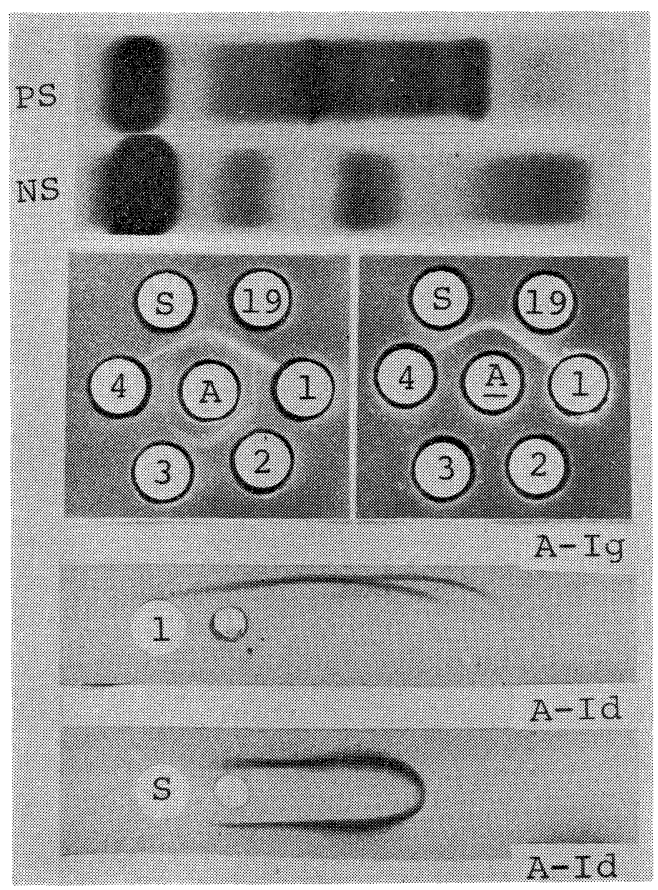

Fig. 1. Anti-Id antibody in patients with WM. The antibody (A) against patient $\operatorname{IgM}(19)$ reacted with other macroglobulinemic sera (1-4), patient serum (PS, S) and the 19S fraction (19). The absorped antibody (A) became idiotypic as shown by double diffusion and immunoelectrophoresis.

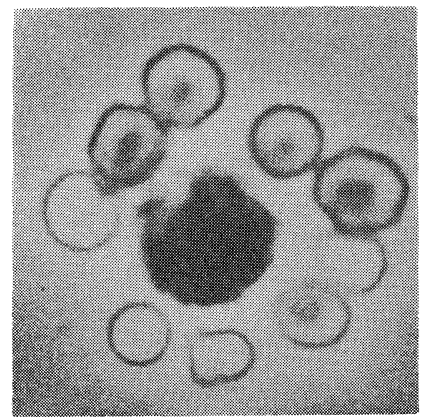

Fig. 2. Id-bearing peripheral blood T cells. Anti-Id treated lymphocytes reacted with SRBC and OxRBC coupled with protein A (dark red blood cells). with autologous $M$ proteins in the peripheral blood of 4 out of 6 patients $^{5)}$. The $T$ cells of one MM patient reacted with the $\mathrm{F}\left(\mathrm{ab}^{\prime}\right) 2$ fragment of IgG M protein.

(2) Cellular anti-tumor immunity against Id determinants of $\operatorname{IgM}$ in $\mathrm{B} / \mathrm{W}$ mice $^{6)}$ : Idspecific immunity against $\operatorname{IgM}$ Id-bearing lymphoma cells was demonstrated in vivo and in vitro by immunizing $\mathrm{B} / \mathrm{W}$ mice with IgM and challenging them with lymphoma cells. Cr-release cytotoxicity assay revealed the anti-Id immunity to be mediated by cellular immunity.

$\mathrm{M}$ protein Id has been used as a distinct marker of $\mathrm{M}$ protein in $\mathrm{MG}$ patients to identify malignant cells in various tissues, to evaluate the effects of therapy and to detect the presence of malignant clones in the early stage. $M$ proteins with autoantibody activity were useful to study the mechanism of autoantibody production, utilizing the cross-specificity between these M proteins and autoantibodies.

The presence of Id-bearing B cells in the peripheral blood of $\mathrm{MG}$ patients indicates that the monoclonal change occurs at the $\mathrm{B}$ cell level. The occurrence of $\mathrm{M}$ protein synthesis upon culture of Id-bearing $\mathrm{B}$ cells and patient- or normal $\mathrm{T}$ cells in the presence of PWM, indicates that Idbearing $\mathrm{B}$ cells in some cases differentiate to $\mathrm{M}$ protein-producing cells with the help of $\mathrm{T}$ cells. Thus, Id-bearing $\mathrm{B}$ cells may retain some of the properties of normal $B$ cells.

Id-bearing $\mathrm{T}$ cells were detected in the peripheral blood of MG patients, however, the pathophysiological nature of these cells is unclear at present. These cells may exist as regulatory $\mathrm{T}$ cells which still have some effect on the proliferation of monoclonal clones.

Anti-Id immunity was evident in our $\mathrm{B} / \mathrm{W}$ mice and naturally occuring suppressive $\mathrm{T}$ cells specific for myeloma Id have been reported in Balb/c mice ${ }^{7)}$. The Idreactive $T(T \gamma$ or $T \mu)$ cells of some $M G$ patients correspond to Id-specific $\mathrm{T}$ cells in mice with myeloma or lymphoma, suggest- 
ing that Id-specific immunity mediated by $\mathrm{T}$ cells occurs in human MG.

Our data suggest that an immunoregulatory mechanism exists and functions in MG patients via recognition of Id determinants of autologous $\mathrm{M}$ proteins.

\section{REFERENCES}

1) Jerne NK: Network theory of the immune system. Ann Immunol (Inst Pasteur) 125C : $373,1974$.

2) Eichmann K: Expression and function of idiotypes on lymphocytes. Adv. Immunol, $26: 195,1978$.

3) Sugai $S$ et al: Non-IgM monoclonal gammopathy in patients with Sjögren's syndrome. Amer J Med, 68: 861, 1980.

4) Sugai S and Konda S: Idiotype-bearing lym- phocytes in the peripheral blood of patients with monoclonal gammopathy. Acta Haematol Jap 42 : 24, 1979.

5) Sugai S and Konda S: Idiotype (Id)-bearing $\mathrm{T}$ cells and Id-reactive $\mathrm{T}$ cells in patients with monoclonal gammopathy. Proc of the Japanese Immunology Meeting 10: 181, 1980 (in Japanese)

6) Sugai S et al : Protective and cellular immune responses to idiotypic determinants on cells from a spontaneous lymphoma of NZB/NZW $\mathrm{F}_{1}$ mice. J Exp Med 140: 1547, 1974.

7) Bona C and Paul WE: Cellular basis of regulation of expression of idiotype. I. Tsuppressor cells specific for MOPC460 idiotype regulate the expression of cells secreting antiTNP antibodies bearing 460 idiotype. J Exp Med 149: 592, 1979. 